\title{
Human sulfatase transiently and functionally active expressed in E. coli K12
}

\section{Raúl A. Poutou-Piñales}

Instituto de Errores Innatos del Metabolismo (IEIM)

Grupo de Biotecnología Ambiental e Industrial (GBAI) Facultad de Ciencias

Pontificia Universidad Javeriana

Cra. 7 N 40-62. Bogotá. D.C., Colombia

E-mail: rpoutou@javeriana.edu.co

Adriana Vanegas Niño

Instituto de Errores Innatos del Metabolismo (IEIM) Facultad de Ciencias

Pontificia Universidad Javeriana

Cra. 7 N 40-62. Bogotá. D.C., Colombia

\section{Patricia Landázuri}

Laboratorio de Bioquímica y Genética

Facultad de las Ciencias de la Salud

Cra 15 Calle 12 Norte. Armenia, Quindío

Universidad del Quindío, Armenia, Colombia

\section{Homero Sáenz $z^{\#}$}

Instituto de Errores Innatos del Metabolismo (IEIM)

Facultad de Ciencias

Pontificia Universidad Javeriana

Cra. 7 N 40-62. Bogotá. D.C., Colombia

\section{Leonardo Lareo ${ }^{\dagger}$}

Grupo de Investigación en Bioquímica Computacional Departamento de Bioquímica. Facultad de Ciencias

Pontificia Universidad Javeriana

Cra. 7 N 40-62. Bogotá. D.C., Colombia

Olga Yaneth Echeverri Peña

Instituto de Errores Innatos del Metabolismo (IEIM) Facultad de Ciencias

Pontificia Universidad Javeriana

Cra. 7 N 40-62. Bogotá. D.C., Colombia

Luis A. Barrera Avellaneda*

Instituto de Errores Innatos del Metabolismo (IEIM) Facultad de Ciencias

Pontificia Universidad Javeriana

Cra. 7 N ${ }^{\circ}$ 40-62. Bogotá. D.C., Colombia

E-mail: abarrera@javeriana.edu.co

Financial support: Instituto Colombiano para la Ciencia y la Tecnología Francisco José de Caldas (COLCIENCIAS), Grant No. 1203-12-10410-192-2000 and Pontificia Universidad Javeriana, Bogotá, D.C., Colombia, Grant No. 120104-O-0101103.

Keywords: E. coli, glycation, human sulfatase, transient expression.

Present address: "Unidad de Biología Celular y Microscopía, Decanato de Medicina, Universidad Centrocidental Lisandro Alvarado, Ave. Libertador Ave. Andres Bello, Barquisimeto, Venezuela.

Abbreviations: ER: endoplasmic reticulum

hIDS: human iduronate 2-sulfate sulfatase (native protein)

hrIDS: human recombinant iduronate 2-sulfate sulfatase

*Corresponding author 
MCB: master cell bank

MPS II: Hunter syndrome or mucopolysacharidosis type II

OD: optical density

$P_{(x)}$ : biomass productivity (dry weight)

$t_{d}$ : duplication time

WCB: working cell bank

$x$ : dry biomass weight

$\mu_{(\mathrm{x})}$ : Specific growth rate

The recombinant human iduronate 2-sulfate sulfatase (hrIDS) was transiently and functionally active expressed in $E$. coli K12. The enzyme activity (crude extract) at $100 \mathrm{ml}$ and $400 \mathrm{ml}$ oscillated between 0.25 and $10.58 \mathrm{nmol} \mathrm{h}^{-1} \mathrm{mg}^{-1}$. The wide Western-blot peptide profile suggest that hrIDS is proteolitically processed "randomly" which agrees with the ultrafiltration assay in which the hrIDS activity was found in all fractions ( $<30 \mathrm{kDa}, 30-100 \mathrm{kDa}$ and $>100 \mathrm{kDa}$ ). No glycation sites were found by computer analysis of the hIDS sequence; discarding the possibility of marks for glycation and proteolytic processing.

Human iduronate 2-sulfate sulfatase (hIDS) (E.C. 3.16.1.3) is a lysosomal enzyme that catalyzes the hydrolysis of the C2-sulphate ester bond from both heparan and dermatan sulphate. The hIDS deficiency causes the Hunter Syndrome or Mucopolysacharidosis type II (MPS II); the severe form of MPS II exhibits skeletal deformity, airway obstruction, cardiac disease, progressive mental retardation and a life span of about 15 years (Neufeld and Muenzer, 2001).

The hIDS has been purified and characterized from plasma, urine, placenta, liver, kidney, intestine and fibroblasts (Cudry et al. 1999); the recombinant protein has been expressed in Pichia pastoris, Linfoblastoid and COS cells (Millat et al. 1998; Mendoza et al. 2008; Córdoba-Ruiz et al. 2009; Landázuri et al. 2009). In Linfoblastoid and COS cells it has been found that the mature forms presents a molecular weight between $45-55 \mathrm{kDa}$. As other members of the sulfatases family, the hIDS undergo a common posttranslational modification in which a Cys or Ser residue at the active enzyme core is converted into FGly (Schmidt et al. 1995; Dierks et al. 1998a; Dierks et al. 1998b; Knaust et al. 1998; Dierks et al. 1999; Waldow et al. 1999). The Cys at position 84 in hIDS is co-translationally modified to formylglycine (FGly) within the endoplasmic reticulum (ER) to produce an active enzyme (von Figura et al. 1998).

Considering several facts like i) the Enzyme Replacement Therapy (ERT) is a promising option for MPSII treatment success (Byers et al. 2000; Ioannou et al. 2001; Kakkis, et al. 2001; Desnick, 2004), ii) in general terms the ERT cost oscillate between $\$ 100.000$ to $\$ 200,000.00$ USA/year/patient (Mehta et al. 2003; Wraith, 2006), which is not sustainable by the social security health service in developing countries, iii) differences found in the glycosilation pattern in human and yeast (Trimble et al. 1991), and iv) the importance of both N-glycosilation and manose-6-phosphate pattern in protein structure, stability, activity, and receptor recognition, etc. (Robert et al. 1998; Parodi, 2000; Helenius and Aebi, 2001; LeBowitz et al. 2004); we expressed the hrIDS in E. coli K12, with the main object of biochemical studies and chemical addition of the N-glycosilation-manose-6-phosphate pattern as strategy to address the recombinant protein to the target tissue. Reasons why it is important to improve the expression of hrIDS in a suitable system as E. coli.

\section{MATERIALS AND METHODS}

\section{Strains and genetic construction}

A cDNA fragment of $1.7 \mathrm{~Kb}$ coding for the enzyme hIDS was inserted into an EcoRI restriction site in M13amp11 (+) Strand of pUC13 $(2.9 \mathrm{~kb})$ under the control of lac promoter from E. coli. The size of the construct (pUC13hrIDS) was $\sim 4.4 \mathrm{~kb}$. Competent cells of E. coli K12 JM109 (recA1 supE44 endA1 hsdR17 gyrA96 relA1thi $\Delta$ (lacpro $\mathrm{AB}) \mathrm{F}^{\prime}$ [tra $\mathrm{D} 36$ pro $\mathrm{AB}+$ lacIq lacZ $\Delta \mathrm{M} 15$ ) were used for transformation and transient expression of the recombinant protein (hrIDS). The classical transformation procedure described by Sambrook (Sambrook and Russell, 2001) was used to introduce the pUC13-hrIDS into JM109. The cells were plated on Luria-Bertani (LB or LBA) with or without $50 \mu \mathrm{g} \mathrm{ml}^{-1}$ of ampicilline. Several positive colonies were grown in LBA broth to prepare a master cell bank (MCB) which was conserved at $-70^{\circ} \mathrm{C}$ (Meza et al. 2004).

\section{Shake flask cultures}

Batch cultures were carried out in $500 \mathrm{ml}$ shake flasks containing $100 \mathrm{ml}$ of minimal culture media MM $(0.05 \mathrm{M}$ $\mathrm{K}_{2} \mathrm{HPO}_{4} / \mathrm{KH}_{2} \mathrm{PO}_{4}$, pH $7.2 \pm 0.2 ; 0.1 \%$ w/v NH $\mathrm{NH}_{4} \mathrm{Cl}, 0.01 \%$ $\mathrm{w} / \mathrm{v} \quad \mathrm{MgCl}_{2} \cdot 6 \mathrm{H}_{2} \mathrm{O}, \quad 0.001 \% \quad \mathrm{w} / \mathrm{v} \quad \mathrm{NaCl} ; \quad 0.001 \% \quad \mathrm{w} / \mathrm{v}$ $\mathrm{MnCl}_{2} .4 \mathrm{H}_{2} \mathrm{O} ; 0.001 \% \mathrm{w} / \mathrm{v} \mathrm{FeCl} 3.6 \mathrm{H}_{2} \mathrm{O} ; 0.5 \% \mathrm{w} / \mathrm{v}$ xylose, 3 $\mathrm{mM}$ methionine, $3 \mathrm{mM}$ tyramine). Alternatively, $100 \mathrm{ml}$ of Luria Bertani (LB) media were used. Both media were supplemented or not with $3 \mathrm{mM}$ of tyramine and $50 \mu \mathrm{g} \mathrm{ml}^{-1}$ of ampicilline, depending of treatment (MMT, MMAT, LBT and LBAT) and strain assayed (JM109/pUC13, JM109/pUC13-hrIDS). All cultures were incubated at $30^{\circ} \mathrm{C}$, 250 r.p.m., during 24 hrs.

With the object to evaluate the production consistence (at low scale) and to corroborate the transient expression, a $2000 \mathrm{ml}$ shake flask culture assay, was carried out with 400 
$\mathrm{ml}$ of LBAT at $30^{\circ} \mathrm{C}, 200$ r.p.m., during 8 hrs. This assay was repeated 16 times.

In both shake flask scale (100 and $400 \mathrm{ml})$, the bacterial behavior was followed every $2 \mathrm{hrs}$ by optical density at 540 $\mathrm{nm}\left(\mathrm{OD}_{540 \mathrm{~nm}}\right)$ in a Multiskan MCC/340 Labsystems; data collected were mathematically transformed into dry biomass weight $x\left(\mathrm{~g} \mathrm{~L}^{-1}\right)$ by using a calibration curve represented by Equation 1 .

$y=0.5698 X$ with $\mathrm{r}^{2} 0.9674$

\section{[Equation 1]}

The data of $x$ ( $\left(\mathrm{g} \mathrm{L}^{-1}\right.$ of dry biomass weight), was transformed as $\operatorname{Ln}\left(x / x_{0}\right)$ and plotted vs. time (h); the slope of this curve (exponential phase) was used to calculate the specific growth rate $\mu_{(x)}\left(\mathrm{h}^{-1}\right)$ and duplication time $t_{d}(\mathrm{~h})$ as follow.

$$
\psi_{(x)}=\frac{1}{x} \frac{d x}{d t}
$$

[Equation 2]

$L n x=L n x_{0}+\mu_{i x} t$

[Equation 3]

$\operatorname{Ln}\left(\frac{x}{x_{0}}\right)=\mu_{(x)^{t}} \quad$ (where $\left.t=t_{\text {log ghase }}-t_{\text {lag phase }}\right)$

[Equation 4]

$$
t_{d}=\frac{\operatorname{Ln} 2}{\mu_{(x)}}
$$

[Equation 5]

Total extra and intracellular proteins $\left(\mathrm{mg} \mathrm{ml}^{-1}\right)$ of samples were estimated by Lowry method.

\section{Statistical analysis}

Post Hoc test (Duncan) and One-way ANOVA analysis. Two transformed strains were assayed in $100 \mathrm{ml}$ of culture media; JM109/pUC13 as negative control because it lack the cDNA for hIDS, and JM109/pUC13-hrIDS as producing strain; both strains were assayed in both LB and MM culture media supplemented or not with $3 \mathrm{mM}$ of tyramine (named as treatments), T3: Media LBA, T4: Media LBA + $3 \mathrm{mM}$ tyramine, T7: Media MMA, and T8: Media MMA + 3 mM tyramine).

A Duncan test was carried out to generate homogeneous groups, as complement of ANOVA. Two one-way ANOVA analysis were carried out; the first to compare T3, $\mathrm{T} 4, \mathrm{~T} 7$ and $\mathrm{T} 8$ in terms of biomass productivity $\left(\mathrm{P}_{(\mathrm{x})}\right)$ and the second to compare the maximal enzyme activity (Max. Enz. Act.), with a significance grade of 0.05 ; the hypothesis was:

Ho: $\mu_{1}=\mu_{2}=\mu_{3}=\ldots=\mu_{\mathrm{n}}$
Hi: at least one of the $\mu$ is different

If $\mathrm{p}>0.05 \mathrm{Ho}$ is not rejected

If $\mathrm{p}<0.05 \mathrm{Ho}$ is rejected

and

$P_{(X)}=\frac{[\text { biomass }]}{t}$ (where $t$ is the culture time for highest biomass dry weight)

[Equation 6]

\section{Pellet disruption}

Each sample was treated as follows: cells were collected by centrifugation at $5000 \mathrm{~g}, 5 \mathrm{~min}$ and $4^{\circ} \mathrm{C}$. The supernatant was stored at $-20^{\circ} \mathrm{C}$ until use. The pellet was suspended in lysis buffer, $(50 \mathrm{mM}$ Tris-HCl pH 7.5 $\pm 0.2,200 \mathrm{mM} \mathrm{NaCl}$, $5 \% \mathrm{v} / \mathrm{v}$ glycerol, $1 \mathrm{mM}$ dithiotreitol, $1 \mathrm{mM}$ PMSF) with $300 \mu \mathrm{g} \mathrm{ml}^{-1}$ lysozime, and incubated $1 \mathrm{hr}$ at $4^{\circ} \mathrm{C}$. After incubation, cells were treated with 4 cycles of freezing and thawing $\left(5 \mathrm{~min}\right.$ in liquid $\mathrm{N}_{2}$ and $5 \mathrm{~min}$ at $37^{\circ} \mathrm{C}$ ) and centrifuged at $4000 \mathrm{~g}$ for $10 \mathrm{~min}$. Both, cell lysate and culture supernatant were assayed for hrIDS activity and ultrafiltration assay.

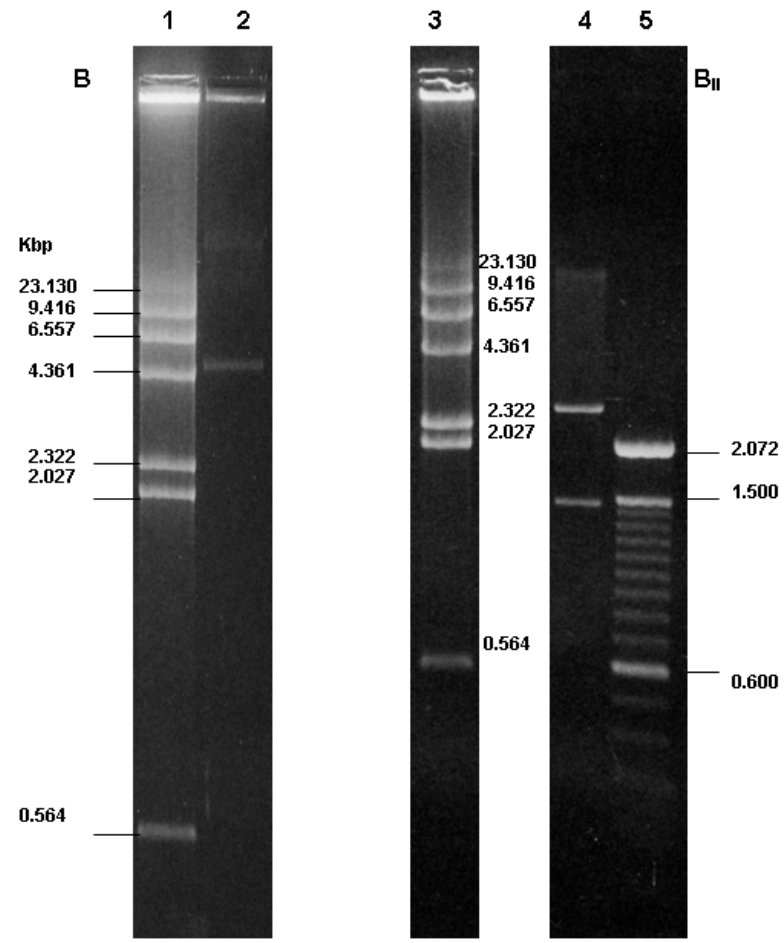

Figure 1. Construct of hrIDS transformed in E. coli JM109. Photography of two different $1 \% \quad \mathrm{w} / \mathrm{v}$ agarose gel electrophoresis (B, BII), stained with $0.25 \% \mathrm{w} / \mathrm{v}$ of ethidium bromide; showing, $\lambda$ DNA-Hind III Marker (B and BII-3), pUC13hrIDS construct (B-2), pUC13-hrIDS digested with EcoRI (BII-4) and $100 \mathrm{pb}$ DNA Ladder Marker (BII-5). The excision of hrIDS fragment from pUC13-hrIDS with ECoRI means a $1.5 \mathrm{~kb}$ fragment. 

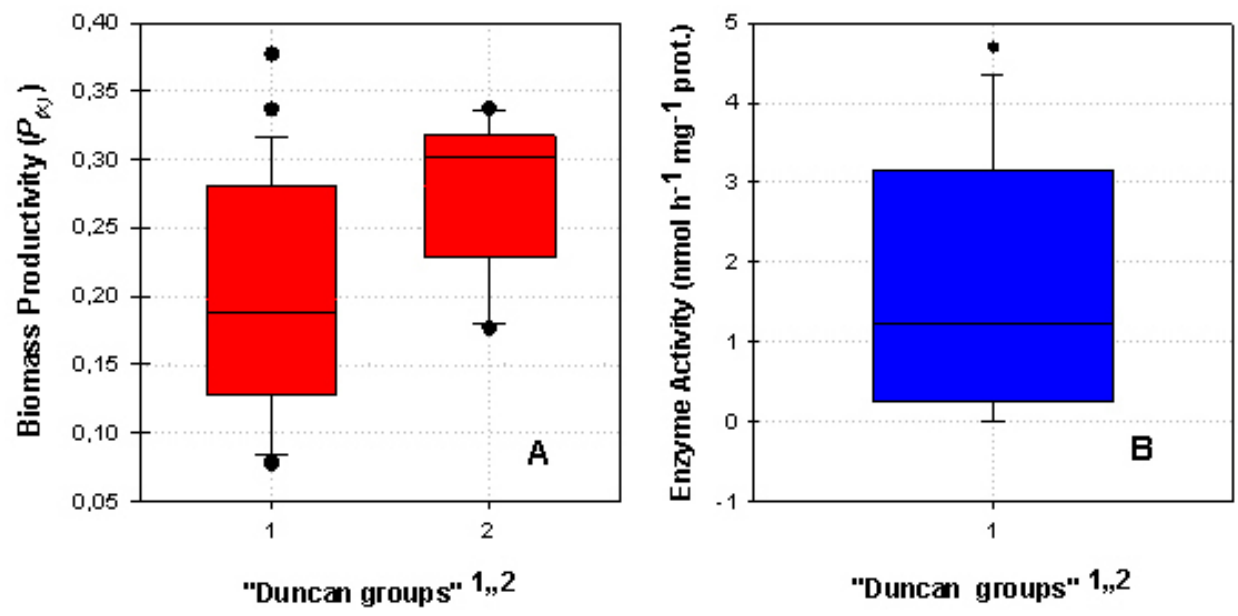

\begin{tabular}{|c|c|c|c|c|c|}
\hline \multirow{2}{*}{$P_{(x)}\left(g L^{-1} h^{-7}\right)$} & \multicolumn{5}{|c|}{ ANO VA analysis } \\
\hline & Sum of Squares & df & Mean Square & $\mathbf{F}$ & Sig \\
\hline Between Groups & 0.068 & 3 & 0.023 & 3.962 & 0.018 \\
\hline Within Groups & 0.166 & 29 & 0.006 & & \\
\hline Total & 0.234 & 32 & & & \\
\hline
\end{tabular}

\begin{tabular}{|c|c|c|c|c|c|}
\hline \multirow{2}{*}{$\begin{array}{c}\text { Enz. Act (nmol } h^{-1} \\
\left.m g^{-1} \text { prot }\right)\end{array}$} & \multicolumn{5}{|c|}{ ANO VA analysis } \\
\hline & Sum of Squares & df & Mean Square & $\mathbf{F}$ & Sig \\
\hline Between Groups & 6.300 & 3 & 2.100 & 0.606 & 0.626 \\
\hline Within Groups & 34.676 & 10 & 3.468 & & \\
\hline Total & 40.976 & 13 & & & \\
\hline
\end{tabular}

Figure 2. Duncan test (graphics A and B) and One-way ANOVA (tables A and B) comparing the treatments T3, T4, T7 and T8: A. biomass productivity $\left(P_{(x)}\right.$ as $\left.\mathrm{gL}^{-1} \mathrm{~h}^{-1}\right)$, B. enzyme activity (Enz. Act. as $\mathrm{nmol} \mathrm{h} \mathrm{mg}^{-1}$ prot).

\section{Enzyme activity}

The supernatant $(10 \mu \mathrm{l})$ of fermentation was mixed every 2 hrs with $20 \mu \mathrm{l}$ of substrate solution containing $1.25 \mathrm{nM}$ of 4-methylumbelliferyl- $\alpha$-iduronate 2-sulphate (MU- $\alpha$ IdoA$2 \mathrm{~S}$ ) dissolved in $0.1 \mathrm{M} \mathrm{CH} \mathrm{COONa}_{3} \mathrm{CH} \mathrm{CH}_{3} \mathrm{COO} \mathrm{pH} 5.0 \pm 0.2$ and $10 \mathrm{mM} \mathrm{Pb}\left(\mathrm{CH}_{3} \mathrm{COO}\right)_{2} \cdot 3 \mathrm{H}_{2} \mathrm{O}$. It was incubated at $37^{\circ} \mathrm{C}$ for $4 \mathrm{hrs}$, after which were added $40 \mu \mathrm{l}$ of $\mathrm{Pi} / \mathrm{Ci}$ buffer $\left(\mathrm{NaH}_{2} \mathrm{PO}_{4} 0.4 \mathrm{M}, \mathrm{C}_{6} \mathrm{H}_{5} \mathrm{Na}_{3} \mathrm{O}_{7} .2 \mathrm{H}_{2} \mathrm{O} 0.2 \mathrm{M}\right.$ pH $4.5 \pm 0.2 \mathrm{y}$ $\mathrm{NaN}_{3} 0.02 \% \mathrm{w} / \mathrm{v}$ ) and $10 \mu \mathrm{l}$ de LEBT. The solution was incubated to $37^{\circ} \mathrm{C}$ for $37 \mathrm{hrs}$. The reaction was stopped with $650 \mu \mathrm{l}$ of stop buffer $\left(\mathrm{NaHCO}_{3} / \mathrm{NaCO}_{3} 0.5 \mathrm{M}, \mathrm{pH} 10.7 \pm\right.$ 0.2 , with glycine $1.7 \mathrm{mM}$ ). The fluorescence was determined in a fluorometer Turner 450, with wave lengths of excitation and emission of 360 and $415 \mathrm{~nm}$, respectively (Voznyi et al. 2001). Protein concentration was determined by the Lowry method; the total enzyme activity was expressed as $\mathrm{nmol} \mathrm{h}^{-1} \mathrm{mg}^{-1}$ of total protein. Plasma and human leukocytes were used as controls for the hIDS activity test, taking into account the reference values detected at the laboratory.

\section{Ultrafiltration assay}

Once the culture was centrifuged at $2500 \mathrm{~g}$ for $20 \mathrm{~min}$ at $4^{\circ} \mathrm{C}$; the supernatant and the extract of the cellular rupture were processed by ultrafiltration using the AMICON system with a sequential change of YM-100 and YM-30 cellulose membranes to exclude molecules bigger than 100 $\mathrm{kDa}$ and smaller ones than $30 \mathrm{kDa}$, respectively. Fractions were collected and identified as $>100 \mathrm{kDa}$ (F1), 30-100 $\mathrm{kDa}(\mathrm{F} 2)$ and $<30 \mathrm{kDa}(\mathrm{F} 3)$ and assayed for hrIDS activity.

\section{Western blot analysis}

Samples (cell lysate or culture supernatant) containing 10 $\mu \mathrm{g}$ of total protein were added to equal volume of $1 \mathrm{X}$ SDS loading buffer $(50 \mathrm{mM}$ Tris- $\mathrm{HCl} \mathrm{pH} 6.8 \pm 0.2 ; 100 \mathrm{mM}$ dithiotreitol; $2 \% \mathrm{w} / \mathrm{v}$ SDS; $0.1 \% \mathrm{w} / \mathrm{v}$ bromophenol blue and $10 \% \mathrm{v} / \mathrm{v}$ glycerol). Proteins were separated by $8 \% \mathrm{w} / \mathrm{v}$ and $12 \% \mathrm{w} / \mathrm{v}$ SDS-PAGE, and transferred to a nitrocellulose membrane (Hybond) by transverse electrophoresis at $30 \mathrm{~V}$ and $4^{\circ} \mathrm{C}$ overnight. The membrane was blocked at $4^{\circ} \mathrm{C}$ overnight in $5 \% \mathrm{w} / \mathrm{v}$ skim milk in buffer TBS $(10 \mathrm{mM}$ Tris$\mathrm{HCl}, \mathrm{pH} 8.0 \pm 0.2 ; 150 \mathrm{mM} \mathrm{NaCl}$ ) containing $0.05 \% \mathrm{v} / \mathrm{v}$ Tween 20. It was then incubated overnight with the monoclonal antibody anti-hIDS (1:250 in 1\% w/v BSA in TBS). Immune complexes were detected with horseradish peroxidase-labelled antibody (1:2000 in $1 \% \mathrm{w} / \mathrm{v}$ BSA in TBS) using the ECL system (Amersham-Pharmacia). The monoclonal antibody (anti-hIDS) was donated by Dr. Kazuko Sukegawa from Gifu University, Japan. 

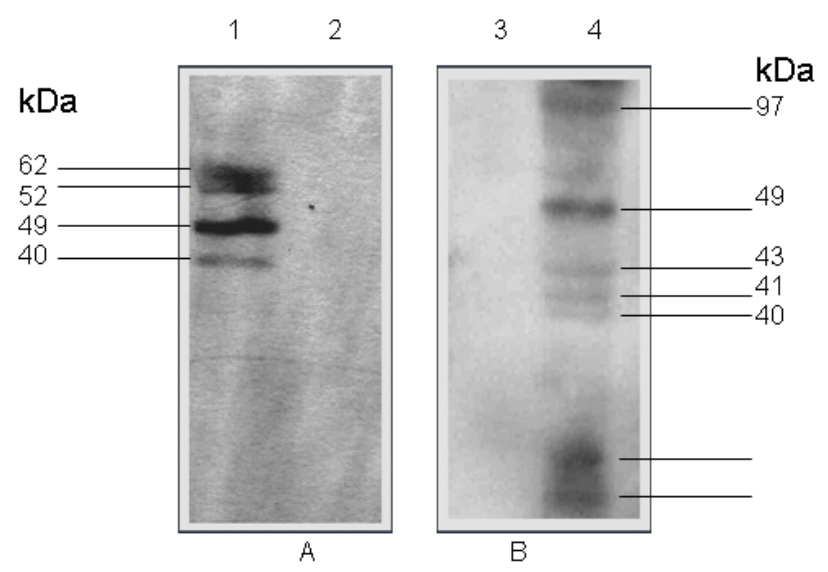

Figure 3. Western-blot detection of hrIDS expressed in $E$. coli using an anti-hIDS monoclonal antibody and ECL detection.

A: (Western-blot from $8 \%$ w/v SDS-PAGE).

B: (Western-blot from $12 \%$ w/v SDS-PAGE).

1A: JM109/pUC13-hrIDS cell lysate, 2A: cell lysate, 3B: culture supernatant, 4B: culture supernatant and JM109/pUC13.

\section{Computer analysis of the hIDS}

The access codes for hIDS sequence are AAA63197 (Gene Bank), 91046030 (Medline) and 2122463 (PubMed). The sequence was obtained starting from the conceptual translation of the cDNA (Wilson et al. 1993) and was used for the study of possible glycation sites. The computer analysis allowed the prediction of the glycation profile through the NetGlycate 1.0 software; available at
http://www.cbs.dtu.dk/services/NetGlycate-1.0

(Bo-

\section{RESULTS}

To express the active hrIDS in E. coli, the cDNA $(1.7 \mathrm{~Kb})$ of hIDS was inserted into the multiple cloning sites of pUC13; the final construction pUC13-hIDS was transformed into JM109.

The cDNA insertion in the pUC13 vector was verified digesting the constructs with $E c o R$ I and two bands of 2.9 and $1.5 \mathrm{~Kb}$ respectively were observed (Figure 1, BII-4).

Table 1 shows the results of kinetic parameters as $t_{d}, \mu(x)$, $P_{(x)}$ and average of biological activity of hrIDS enzyme (crude extract) in $100 \mathrm{ml}$ cultures, as results of culture media and tyramine addition.

The first One-way ANOVA analysis (T3, T4, T7 and T8) found a $p<0.50(0.018)$ for biomass productivity; indicating that Ho is rejected; therefore exist significant differences in growth, between LBA and MMA supplemented or not with $3 \mathrm{mM}$ of tyramine with JM109/pUC13-hrIDS, (Figure 2A).

The second One-way ANOVA analysis (T3, T4, T7 and T8) found a $p>0.50(0.626)$ for the enzyme activity; indicating that Ho is not rejected; therefore there is not a significant differences in the enzyme activity detected when using LBA or MMA culture media supplemented or not with $3 \mathrm{mM}$ of tyramine with JM109/pUC13-hrIDS (Figure 2B). When tyramine concentration was increased up to 10

Table 1. Average data of kinetic parameters of negative controls and treatments (T3, T4, T7 and T8) at $100 \mathrm{ml}$.

\begin{tabular}{|c|c|c|c|c|c|}
\hline $\begin{array}{l}\text { Treatment or negative controls (media- } \\
\text { strain) }\end{array}$ & $\mu_{(x)}\left(h^{-1}\right)$ & $t_{d}(h)$ & $\left(g^{-1} h^{-1}\right)$ & n & $\begin{array}{c}\text { hrIDS Act: } \\
\left(\text { nmol h} \mathrm{mg}^{-1}\right)\end{array}$ \\
\hline LB-JM109/pUC13 & 0.27 & 2.60 & 0.40 & 5 & ND \\
\hline LBT*-JM109/pUC13 & 0.34 & 2.00 & 0.30 & 5 & ND \\
\hline T3 & 0.28 & 2.50 & 0.30 & 5 & 1.400 \\
\hline T4 & 0.28 & 2.60 & 0.30 & 5 & 2.500 \\
\hline MM-JM109/pUC13 & 0.26 & 2.65 & 0.10 & 5 & ND \\
\hline MMT $^{\S}$-JM109/pUC13 & 0.25 & 2.76 & 0.10 & 6 & ND \\
\hline T7 & 0.25 & 2.73 & 0.20 & 6 & 1.200 \\
\hline T8 & 0.25 & 2.74 & 0.23 & 8 & 1.900 \\
\hline
\end{tabular}

Where: $\left({ }^{*}\right) 3 \mathrm{mM}$ of tyramine, $\left({ }^{\S}\right) 10 \mathrm{mM}$ of tyramine, $(\mathrm{n})$ number of experiment, $\left(\mathrm{t}_{\mathrm{d}}\right)$ time of duplication and $\left(\mu_{\mathrm{x}}\right)$ growth specific velocity, $(\mathrm{ND})$ no detectable activity, $(P(x))$ biomass productivity. 
mM neither $P_{(x)}$ nor enzyme activity was increase (data not shown).

Taking into account the previous reasons the LBAT (T4) was selected for two purposes, as culture media for low scale production and to analyze the production consistence at $400 \mathrm{ml}$ scale.

To analyze the consistency of the hrIDS at $400 \mathrm{ml}$ scale "production", several cultures $(\mathrm{n}=16)$ with $400 \mathrm{ml}$ of LBAT were made. The final incubation time did oscillate between $8 \mathrm{hrs}$ to $10 \mathrm{hrs}$ when the log phase is finishing. The hrIDS biological activity did oscillate between 0.25 to $10.58 \mathrm{nmol} \mathrm{h}^{-1} \mathrm{mg}^{-1}$ proteins, with an average of $3.898 \pm$ $3.3913 \mathrm{nmol} \mathrm{h}^{-1} \mathrm{mg}^{-1}$ protein (VC 87\%). The average of the kinetic parameters measured were $\mu(x) 0.36 \pm 0.016 \mathrm{~h}^{-1}(\mathrm{VC}$ $4.4 \%), t d 1.9 \pm 0.090 \mathrm{~h}(\mathrm{VC} 4.5 \%)$ and $P_{(x)} 0.1 \pm 0.004 \mathrm{~g}$ $\mathrm{L}^{-1} \mathrm{~h}^{-1}$ (VC 3.98\%).

The hrIDS was detected by Western-blot on the culture fractions of JM109/pUC13-hrIDS. The anti-human IDS ( $\alpha$ hIDS) monoclonal antibody recognized an intense band of $49 \mathrm{kDa}$ and three others around 62,52 and $40 \mathrm{kDa}$ at culture supernatant (Figure 3A-1). In the cell lysates, five bands of $97,49,43,41$ and $40 \mathrm{kDa}$ were recognized. In addition, two bands with molecular weight below $40 \mathrm{kDa}$ were also detected (Figure 3B-4).

The presence of the hIDS and its activity in each ultrafiltrated fraction revealed an unexpected protein processing (Table 2).

In all activity tests developed during this study, serum or human leukocytes were used as positive control samples. The results were $13.43 \pm 2.72 \mathrm{nmol} \mathrm{h}^{-1} \mathrm{mg}^{-1}$ of total protein, with $n=36$ and $6.01 \pm 1.08 \mathrm{nmol} \mathrm{h}^{-1} \mathrm{mg}^{-1}$ of total protein for $\mathrm{n}=10$ respectively. Both controls were inside of the normal reference values for our laboratory.
In order to verify the possibility that a glycation process has occurred (non-enzymatic glycosilation) reason for both cross-linking and proteolysis marks (Mironova et al. 2001; Mironova et al. 2003); a computer analysis was conducted to analyze the hIDS sequence, but the analysis did not show glycation sites (Figure 4).

\section{DISCUSSION}

Several bacteria of the Enterobacteriaceae family, express a natural arylsulfatase activity (E.C. 3.1.6.1) (Kertesz, 2000) and it has been shown the regulation of this enzyme by methionine (non-repressing conditions), sulphur compounds (repressing conditions) and tyramine (derepressing conditions) (Kertesz, 2000). Sulfatase activity has not been detected in $E$. coli $\mathrm{K} 12$; but considering that $E$. coli harbors the FGly generating system (Dierks et al. 1998b; Benjdia et al. 2007), it was selected in this work as a useful model to intent the expression of hrIDS. The cDNA encoding the hIDS was inserted into the pUC13 under the control of E. coli lac promoter. The hIDS cDNA insertion was confirmed by restriction analysis (Figure 1). The sequence analysis reported a $97 \%$ of homology and a PCR amplification to detect the orientation of the insert (EcoRI flanked) enable us to select the adequate construct (data not shown), for following assays.

The results of tyramine addition to either $\mathrm{MM}$ and $\mathrm{LB}$ culture media did not causes expression of residual sulfatase or increasing expression of hrIDS in E. coli as was expected, neither in the $\mu_{(x),}, t_{d}$ nor hrIDS activity averages (Table 1).

The first One-way ANOVA analysis shows that the tyramine addition causes a significant effect on the strains growth $(\mathrm{p}<0.5)$ but the $\mathrm{F}$ value indicate a low difference between the two Duncan groups generated. The second One-way ANOVA analysis, indicate that no significant

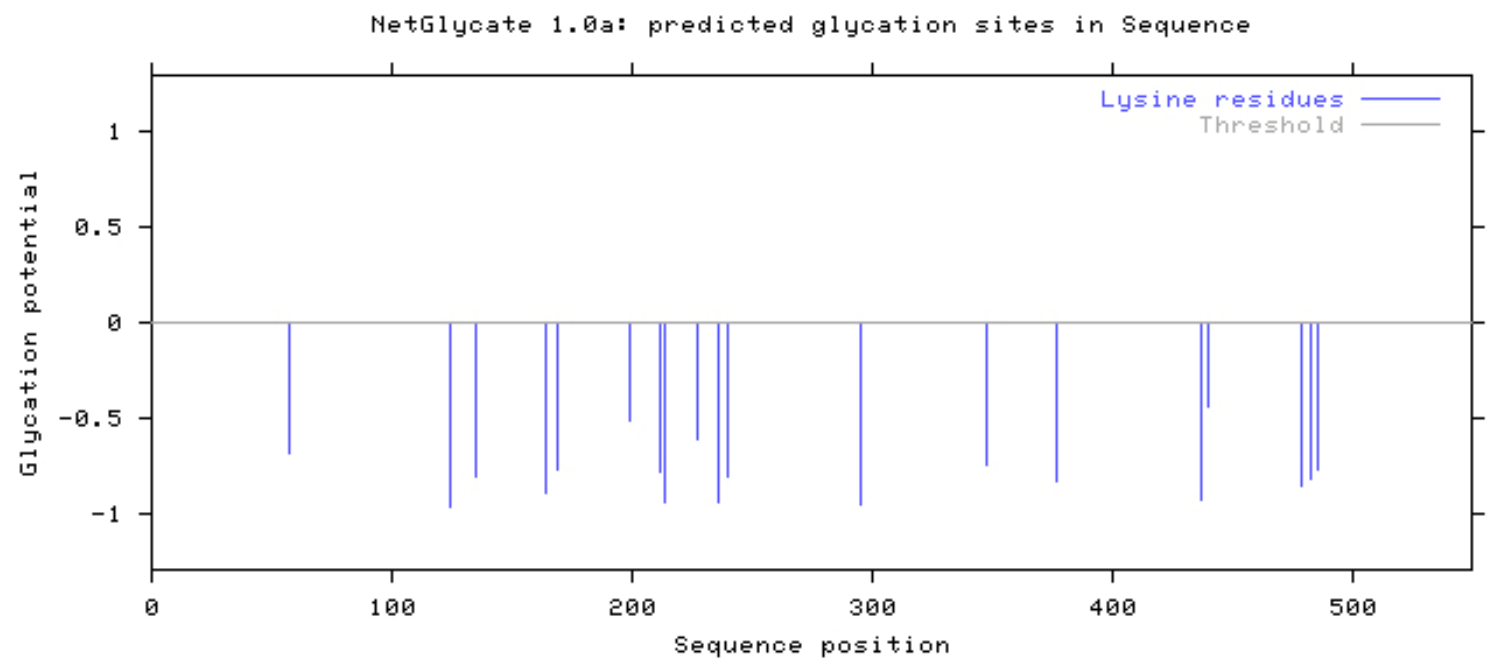

Figure 4. Prediction of glycation sites of hIDS by using NetGlycate 1.0 software. 
difference $(p>0.5)$ for the enzymatic activity were found, but the standard deviation in the only one Duncan group generated makes to think about the variation in the crude extract activity; probably related with the transient expression of the enzyme (Figure 2). The comparison of both Duncan test and One-way ANOVA induce to select the treatment $\mathrm{T} 4$ for the next assay.

Some authors has reported that depending of the type of sulfatase expressed, in some prokaryotes a percentage of the sulfatase produced, carry out the FGly residue at its active site; while another percentage did not; for example the $60 \%$ of the prokaryote arylsulfatase expressed under "strong induction conditions" carry out the FGly residue, while $40 \%$ remain as original amino acids coded in the DNA sequence (Dierks et al. 1998a; Dierks et al. 1998b). In our case, it is probable that a percentage of the expressed hrIDS remain inactive as a result of the non-modification of the $\mathrm{Cys}^{84}$ because of the saturation of the FGly generating system as was suggested by Dierks et al. (1998b). Since it has been demonstrated that prokaryotic system for the modification of Cys presents a similar specificity as the eukaryotic cells (Dierks et al. 1998a; Dierks et al. 1998b; Dierks et al. 1999; Marquordt et al. 2003; Berteau et al. 2006), it is possible that different $E$. coli proteins (possibly not identified) used this system, saturating it (Henderson and Milazzo, 1979). Any way the function or saturation of FGly generating system, and the percentage of inactive hrIDS will have to be experimentally proved.

The results of JM109/pUC13-hrIDS in LBA supplemented with $10 \mathrm{mM}$ of tyramine showed the maximum activity of hrIDS after 6 hrs of culture with $1.20 \mathrm{nmol} \mathrm{h}^{-1} \mathrm{mg}^{-1}$ protein and $\mu_{(x)} 0.27 \mathrm{~h}^{-1}$ (data not shown); higher results were obtained with the same clone in LBAT (T4), (Table 1).

Tyramine did not cause any detectable effect as inducer on the expression of a native sulfatase in E. coli JM109. This compound is the substrate of enzymes as the monoamine oxidase (MaoA) (E.C. 1.4.3.6) and phenylacetaldehyde dehydrogenase (PadA), (E.C. 1.2.1.39), promoting to the formation of the aromatic acids, 4-hydroxyphenylacetic and homoprocatechuate (4HPA and HPC), respectively, which are transformed into succinic and pyruvic acids in most $E$. coli serotypes as $\mathrm{B}, \mathrm{C}$ and $\mathrm{W}$; meaning that tyramine is used like a carbon source by the enzymes of the hpa cluster; therefore $E$. coli $\mathrm{K} 12$, which lacks the hpa cluster can only use tyramine like nitrogen source as was expected according to previously published data (Leuschner et al. 1998; Díaz et al. 2001).

The fact that no native sulfatase activity was detected in JM109/pUC13 (negative control) suggests that the sulfatase activity detected in the producing strain (JM109/pUC13hrIDS) belong to the hrIDS.

Considering that LBAT (T4) was an appropriate culture media due to its composition and that tyramine could be use as nitrogen source, several cultures were conducted at 400 $\mathrm{ml}$. The high standard deviation found in the biological activity and the regularity found in the kinetic parameters as $\mu_{(x)}, t_{d}$ and $P_{(x)}$ support the transient expression of the hrIDS.

Taking into account that E. coli doesn't express a native detectable sulfatase activity even when tyramine is added to the culture media and that immunologic crossed reaction is positive when the arylsulfatase "pseudogene" is present and expressed (Yamada et al. 1978), the Western-blot profile findings could be related to an E. coli proteolytic cleavage but it has to be proved in a future.

The hrIDS peptide profiles detected by Western-blot and the hrIDS activity in ultrafiltrated fractions (Table 2), suggest that several isoforms of the enzyme are active. Thus, it is possible to formulate two questions that have to

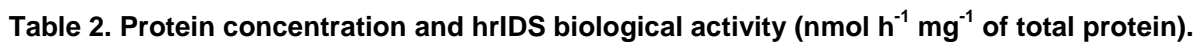

\begin{tabular}{|c|c|c|}
\hline Fraction & $\begin{array}{l}\text { Protein concentration } \\
\qquad\left(\mathrm{mg} \mathrm{ml}^{-1}\right)\end{array}$ & $\begin{array}{c}\text { hrlDS activty } \\
\text { (nmol } \mathrm{h}^{-1} \mathrm{mg}^{-1} \text { of total protein) }\end{array}$ \\
\hline Supernatant & 3.93 & 1.20 \\
\hline$>100$ kDa (F1) & 3.78 & 1.19 \\
\hline 30-100 kDa (F2) & 2.81 & 1.86 \\
\hline$<30 \mathrm{kDa}(\mathrm{F} 3)$ & 3.59 & 0.40 \\
\hline Cell lysate & 1.55 & 2.82 \\
\hline
\end{tabular}

Values of hrIDS activty are represented as nmol of transform substrate (4-methylumbelliferyl-a-iduronate 2-sulphate)/ mg of total protein, (Voznyi et al. 2001). 
be solved with further experiments: Firstly, does E. coli process the hrIDS randomly? Secondly, is the proteolysis processing the result of glycation events?

Mironova et al. 2001 studied the non-enzymatic glycosylation of hrIFN- $\gamma$ expressed in $E$. coli after of the purification and in spite of protein maintenance in a protease-free media. They found the hrIFN- $\gamma$ affected like a glycate protein able to suffer progressive cross-linking and fragmentation processes, demonstrating that in E. coli, an advanced state of glycation took place. The authors proposed the existence of a protease-independent pathway for protein degradation in E. coli. They also took into consideration that glycation "in vivo" could be the consequence of over-expression of the hrIFN- $\gamma$ (Mironova et al. 2001; Mironova et al. 2003), which could have caused inclusion bodies formation.

The results of Western-Blot in this work suggest that the fragmentation of the recombinant protein could be related with proteolytic degradation processes. However, the concomitant appearance of 97-120 $\mathrm{kDa}$ bands and the hrIDS activity found at F1 (Table 2) indicate the possible presence of covalent dimmers, due to Cys content of hIDS (6 residues) or to intermolecular covalent cross-linking, as was found in hrIFN- $\gamma$ expressed in E. coli (Mironova et al. 2001). In any case, it has too, to be proved in further investigations.

Bioinformatic analysis of the hIDS, to analyze the possible existence of glycation sites was performed based on the study of the $\mathrm{NH}_{2}$ groups coming from Lys. The software employed (NetGlycate 1.0) uses an algorithm simulating the influence of the acid radical of glutamate (Glu) working as a catalyst for the glycation of lysine (Lys). It has been observed that in general, the acid radicals are located towards the ending C-t of the glycation site while the Lys residuals are located towards the region $\mathrm{N}-\mathrm{t}$ of the glycation site. Using this approach no glycation sites were detected, although the Matthews correlation coefficient for the software was set to 0.58 for the 60 neutral networks employed (Bo-Johansen et al. 2006).

\section{CONCLUDING REMARKS}

The hrIDS expressed in E. coli was functionally active. Moreover, all fractions obtained after ultrafiltration also showed to be enzymatically active. In this study the average hrIDS activity using $400 \mathrm{ml}$ culture was similar to the activity found in $100 \mathrm{ml}$ cultures of $P$. pastoris (data not shown). The Western-blot peptidic profile found in the recombinant $E$. coli, showed that hrIDS was recognized by a monoclonal antibody against the natural protein. In spite of additional studies that will be necessary for consolidation of our preliminary results; the finding of the transient expression of a human active sulfatase in E. coli $\mathrm{K} 12$ is remarkable.

\section{ACKNOWLEDGMENTS}

Special thanks to Drs. Ivonne Venegas de Balzer and Ivonne S. Gutiérrez-Rojas for the critical reading of the manuscript.

\section{REFERENCES}

BENJDIA, Alhosna; DEHÓ, Gianni; RABOT, Sylvie and BERTEAU, Olivier. First evidences for a third sulfatase maturation system in prokaryotes from E. coli aslB and ydeM deletion mutants. FEBS Letters, March 2007, vol. 581, no. 5, p. 1009-1014.

BERTEAU, Olivier; GUILLOT, Alain; BENJDIA, Alhosna and RABOT, Sylvie. A new type of bacterial sulfatase reveals a novel maturation pathway in prokaryotes. The Journal of Biological Chemistry, August 2006, vol. 281, no. 32, p. 22464-22470.

BO-JOHANSEN, Morten; KIEMER, Lars and BRUNAK, Søren. Analysis and prediction of mammalian protein glycation. Glycobiology, September 2006, vol. 16, no. 9, p. 844-853.

BYERS, Sharon; CRAWLEY, Allison C.; BRUMFIELD, Leanne K.; NUTTALL, Jacqueline D. and HOPWOOD, JOHN J. Enzyme replacement therapy in a feline model of MPS VI: Modification of enzyme structure and dose frequency. Pediatric Research, January 2000, vol. 47, no. 6, p. 743-749.

CÓRDOBA-RUIZ, Henry A.; POUTOU-PIÑALES, Raúl A.; ECHEVERRI-PEÑA, Olga Y.; ALGECIRA-ENCISO, Nestor A.; LANDÁZURI, Patricia; SÁENZ, Homero and BARRERA-AVELLANEDA, Luis A. Laboratory scale production of the human recombinant iduronate 2-sulfate sulfatase-Like from Pichia pastoris. African Journal of Biotechnology, May 2009, vol. 8, no. 9, p. 1786-1792.

CUDRY, Stéphane; FROISSART, Roseline; BOUTON, Olivier; MAIRE, Iréne. and BOZON, Dominique. The 2.1-, 5.4 and $5.7 \mathrm{~kb}$ Transcripts of the IDS gene are generated by different polyadenylation signals. Biochimica et Biophysica Acta (BBA)- Gene Structure and Expression, October 1999, vol. 1447, no. 1, p. 35-42.

DESNICK, Robert J. Enzyme replacement and enhancement therapies for lysosomal diseases. Journal of Inherited Metabolic Disease, May 2004, vol. 27, no. 3, p. 385-410.

DÍAZ, Eduardo; FERRÁNDEZ, Abel; PRIETO, María A. and GARCIA, José L. Biodegradation of aromatic compounds by Escherichia coli. Microbiology and Molecular Biology Review, December 2001, vol. 65, no. 4, p. 523-569.

DIERKS, Thomas; LECCA, Maria Rita; SCHMIDT, Bernhard and VON FIGURA, Kurt. Conversion of cysteine 
to formylglycine in eukaryotic sulfatases occurs by a common mechanism in the endoplasmic reticulum. FEBS Letters, February 1998a, vol. 423, no. 1, p. 61-65.

DIERKS, Thomas; MIECH, Claudia; HUMMERJOHANN, Jörg; SCHMIDT, Bernhard; KERTESZ, Michael A and VON FIGURA, Kurt. Posttranslational formation of formylglycine in prokaryotic sulfatases by modification of either cysteine or serine. The Journal of Biological Chemistry, October 1998b, vol. 273, no. 40, p. 2556025564.

DIERKS, Thomas; LECCA, Maria RITA; SCHLOTTERHOSE, Petra; SCHMIDT, Bernhard and VON-FIGURA, Kurt. Sequence determinants directing conversion of cysteine to formylglycine in eukariotic sulfatases. The Embo Journal, April 1999, vol. 18, no. 8, p. 2084-2091.

HELENIUS, Ari and AEBI, Markus. Intracellular functions of N-linked glycans. Science, March 2001, vol. 291, no. 5512, p. 2364-2369.

HENDERSON, Mary J. and MILAZZO, Francis H. Arylsulfatase in Salmonella typhimurium: detection and influence of carbon source and tyramine on its syntesis. Journal of Bacteriology, July 1979, vol. 139, no. 1, p. 8087.

IOANNOU, Yiannis A.; ZEIDNER, Ken M.; GORDON, Ronald E. and DESNICK, Robert J. Fabry Disease: Preclinical studies demonstrate the effectiveness of $\alpha$ Galactosidase a replacement in enzyme-deficient mice. American Journal of Human Genetic, December 2001, vol. 68 , no. 1 , p. $14-25$.

KAKKIS, Emil D.; MUENZER, Joseph; TILLER, George E.; WABER, Lewis; BELMONT, John; PASSAGE, Merry; IZYKOWKI, Barbara; PHILLIPS, Jeffrey; DOROSHOW, Robin; WALOT, Irv; HOFT, Richard and NEUFELD, Elizabeth F. Enzyme-replacement therapy in mucopolysaccharidosis I. The New England Journal of Medicine, January 2001, vol. 344, no. 3, p. 182-188.

KERTESZ, Michael A. Riding the sulfur cycle-metabolism of sulfonates and sulfate esters in gram-negative bacteria. FEMS Microbiology Reviews, April 2000, vol. 24, no. 2, p. 135-175.

KNAUST, Andreas; SCHMIDT, Bernhard; DIERKS, Thomas; VON BÜLOW, Rixa and VON FIGURA, Kurt. Residues critical for formylglycine formation and/or catalytic activity of arylsulfatase A. Biochemistry, September 1998, vol. 37, no. 40, p. 13941-13946.

LANDÁZURI, Patricia; POUTOU-PIÑALES, Raúl A.; ACERO-GODOY, Jovanna; CÓRDOBA-RUIZ, Henry A.; ECHEVERRI-PEÑA， Olga Y.; SÁENZ, Homero; DELGADO-BOADA, Julio $M$. and BARRERAAVELLANEDA, Luis A. Cloning and shake flask expression of hrIDS-Like in Pichia pastoris. African Journal of Biotechnology, June 2009, vol. 8, no. 12, p. 2871-2877.

LEBOWITZ, Jonathan H.; GRUBB, Jeffrey H.; MAGA, John A.; SCHMIEL, Deborah H.; VOGLER, Carole and SLY, Willian S. Glycosylation-independent targeting enhances enzyme delivery to lysosomes and decreases storage in mucopolysaccharidosis type VII mice. Proceedings of the National Academy of Sciences of the United States of America, March 2004, vol. 101, no. 9, p. 3083-3088.

LEUSCHNER, Renata G.; HEIDEL, Martina and HAMMES, Walter P. Histamine and tyramine degradation by food fermenting microorganisms. International Journal of Food Microbiology, January 1998, vol. 39, no. 1-2, p. 110.

MARQUORDT, Claudia; FANG, Qinghua; WILL, Elke; PENG, Jianhe; VON FIGURA, Kurt and DIERKS, Thomas. Posttranslational modification of serine to formylglycine in bacterial sulfatases recognition of the modification motif by the iron- sulfur protien AtsB. The Journal of Biological Chemistry, January 2003, vol. 278, no. 4, p. 2212-2218.

MEHTA, Atul B.; LEWIS, Susan and LAVEREY, Christine. Treatment of lysosomal storage disorders: increased awareness and diagnosis are important as treatment is now feasible. British Medical Journal, August 2003, vol. 327, no. 7413 , p. 462-463.

MENDOZA, Diego Fernando; ALGECIRA, Néstor Ariel; CÓRDOBA, Henry and BARRERA, Luis Alejandro. A simple structured model for recombinant IDShr protein production in Pichia pastoris. Biotechnology Letters, October 2008, vol. 30, no. 10, p. 1727-1734.

MEZA, Rodrigo Antonio; MONROY, Andrea Fernanda; MERCADO, Marcela; POUTOU, Raúl Alberto; RODRÍGUEZ, Patricia and PEDROZA, Aura Marina. Study of the stability in real time of cryopreserved strain banks. Universitas Scientiarum, July-December 2004, vol. 9, no. 2, p. 35-42.

MILLAT, Gilles; FROISSART, Roseline; CUDRY, Stéphane; BONNET, Véronique; MAIRE, Iréne and BOZON, Dominique. COS cell expression studies of P86L, P86R, P480L and P480Q, Hunter's disease-causing mutations. Biochimica et Biophysica Acta-Molecular Basis of Disease, March 1998, vol. 1406, no. 2, p. 214-218.

MIRONOVA, Roumyana; NIWA, Toshimitsu; HAYASHI, Hayashi; DIMITROVA, Rositsa and IVANOV, Ivan. Evidence for non-enzymatic glycosylation in Escherichia coli. Molecular Microbiology, February 2001, vol. 39, no. 4, p. 1061-1068. 
MIRONOVA, Roumyana; NIWA, Toshimitsu; DIMITROVA, Rositsa; BOYANOVA, Maya and IVANOV, Ivan. Glycation and post-translational processing of human interferon- $\gamma$ expressed in Escherichia coli. The Journal of Biological Chemistry, December 2003, vol. 278 , no. 51 , p. 51068-51074.

NEUFELD, Elizabeth F. and MUENZER, Joseph. The mucopolysaccharidoses. In: BEAUDET, Arthur L.; SCRIVER, Charles R.; SLY, Willian S. and VALLE, David, eds. The metabolic and molecular bases of inherited disease. New York, 2001, vol. 1, p. 2465-2494.

PARODI, Armando J. Role of N-oligosaccharide endoplasmic reticulum processing reactions in glycoprotein folding and degradation. Biochemical Journal, May 2000, vol. 348 , pt. 1 , p. 1-13.

ROBERT, David L.; WEIX, Daniel J.; DAHMS, Nancy M. and KIM, Jung-Ja P. Molecular basis of lysosomal enzyme recognition: three-dimensional structure of the cationdependent mannose 6-phosphate receptor. Cell, May 1998, vol. 93, no. 4, p. 639-648.

SAMBROOK, Joseph and RUSSELL, David William. Molecular Cloning: A Laboratory Manual. $3^{\text {th }}$ ed., New York; Cold Spring Harbor Laboratory Press, 2001. 2100 p. ISBN: $0879695773,9780879695774$.

SCHMIDT, Bemhard; SELMER, Thorsten; INGENDOH, Arnd and VON FIGURA, Kurt. A novel amino acid modification in sulfatases that is defective in multiple sulfatase deficiency. Cell, July 1995, vol. 82, no. 2, p. 271278.

TRIMBLE, Roibert B.; ATKINSON, Paul H.; TSCHOPP, Juerg F.; TOWNSEND, Reid R. and MALEY, Frank. Structure of oligosaccharides on Saccharomyces $\mathrm{SUC}_{2}$ invertase secreted by methylotrophic yeast Pichia pastoris. The Journal of Biological Chemistry, December 1991, vol. 266 , no. 34 , p. 22807-22817.

VON FIGURA, Kurt; BEMHARD, Schmidt; THORSTEN, Selmer and DIERKS, Thomas. A novel protein modification generating an aldehyde group in sulfatases: its role in catalysis and disease. BioEssays, June 1998, vol. 20, no. 6 , p. $505-510$.

VOZNYI, Ya V.; KEULEMANS, J.L.M. and VAN DIGGELEN, Otto P. A fluorimetric enzyme assay for the diagnosis of MPS II (Hunter disease). Journal of Inherited Metabolic Disease, November 2001, vol. 24, no. 6, p. 675680 .

WALDOW, Anne; SCHMIDT, Bernhard; DIERKS, Thomas; VON BÜLOW, Rixa and VON FIGURA, Kurt. Amino acids residues forming the active site of arylsulfatase A. Rolein catalytic activity and substrate binding. The Journal of Biological Chemistry, April 1999, vol. 274 , no. 18 , p. $12284-12288$.
WILSON, Peter J.; MEANEY, Cathy A.; HOPWOOD, John J. and MORRIS, C. Phillip. Sequence of the human iduronate 2-sulfatase (IDS) gene. Genomics, September 1993, vol. 17, no. 3, p. 773-775.

WRAITH, J.E. Limitations of enzyme replacement therapy: current and future. Journal of Inherited Metabolic Disease, April 2006, vol. 29, no. 2-3, p. 442-447.

YAMADA, Takashi; MUROOKA, Yoshikatsu and HARADA, Tokuya. Comparative Immunological studies on Arylsulfatase in bacteria of family enterobacteriaciae: Occurrence of Arylsulfatase protein by sulfur compounds and tyramine. Journal of Bacteriology, February 1978, vol. 133 , no. 2 , p. $536-541$. 